1 Center for Policy Impact in Global Health, Duke Global Health Institute, Duke University, Durham, NC, USA

2 Department of Medicine, Massachusetts General Hospital, Boston, MA, USA

Correspondence to: G Yamey gavin.yamey@duke.edu @gyamey and @rwalensky on Twitter Cite this as: BMJ 2020;370:m3365 http://dx.doi.org/10.1136/bmi.m3365 Published: 01 September 2020

\title{
Covid-19: re-opening universities is high risk
}

\section{The key is to curb community transmission then provide frequent testing}

\section{Gavin Yamey, ${ }^{1}$ Rochelle P Walensky}

Over a third of US colleges and universities fully reopened in August. ${ }^{1}$ It was risky: at the beginning of the month, the US had about 55000 new cases per day $^{2}$ and no federal covid-19 control plan or coordinated vision for safely reopening universities. Today, the national reopening experiment already looks to have been a disaster.

Major campus outbreaks have led many large universities, including the University of North Carolina Chapel Hill (UNC) and the University of Notre Dame, Indiana, to shut down again. Only a week after classes started on 10 August, most of which were face to face, UNC, home to about 30 ooo students, reported 130 new infections in students and five in employees. ${ }^{3}$ During 1-27 August, there were 756 confirmed new infections at UNC. ${ }^{4}$ This scenario has played out at universities nationwide, ${ }^{5}$ and by 26 August, there had been at least 26 ooo new infections at over 750 colleges and universities. ${ }^{6}$

American universities faced financial pressures to reopen and generally expected campus infections to happen as merely the cost of doing business. But this attitude was cavalier. A multistate US survey found that about a quarter of people with symptomatic covid-19 aged 18-34 years develop post-acute covid, ${ }^{7}$ a potentially disabling illness that can cause severe complications. ${ }^{89}$ One regional US college football competition was cancelled after at least 15 healthy student players developed covid related myocarditis. $^{10}$

Infections in students can also lead to infections among vulnerable people on campus, including faculty members and staff, and in the wider community. ${ }^{11}$ Over $40 \%$ of service and maintenance staff, such as cafeteria workers and housekeeping staff, are people of colour, ${ }^{12}$ who are at higher risk of death and further transmission in their own communities if they become infected.

\section{Lessons from the US}

With students about to return to universities in the UK, what can we learn from the US debacle?

The first lesson is the importance of curbing community transmission before reopening. Community spread can be considered minimal if there is a seven day rolling average of fewer than four new cases per 100 ooo population a day and the test positivity rate is under $5 \% .{ }^{13}$ Such criteria were not met in North Carolina before UNC's reopening. In a study of Taiwan's successful reopening of universities, a key factor was the country almost eliminating community spread first. ${ }^{14}$ In the month leading up to reopening, there were just five or fewer new daily cases nationwide. In the US, Boston University reopened in a state (Massachusetts) with low community transmission rates and has had only 32 infections since July $27 .{ }^{15}$

The second lesson is the value of quarantining before or on arrival. Even if a university lies in an area with low community transmission, in the US many arriving students came from high transmission states or overseas. Universities that have required students to quarantine for 14 days before classes start report low test positivity rates among students. ${ }^{16}$

Many outbreaks in US universities have been in congregate settings-such as dorms and off-campus housing-pointing to a third lesson. Viral transmission between asymptomatic students can occur at lightning speed in these settings. Adopting symptom based covid-19 screening, as used by many universities, is not a robust prevention strategy. The US Centers for Disease Control and Prevention (CDC), highly politicised under the Trump administration, gave universities cover by stating that it "does not recommend entry testing of all returning students."17 And many universities, unfortunately, followed suit.

This recommendation is not evidence based. Model based evidence shows that preventing outbreaks requires high frequency screening of all students on campus. An epidemic modelling study found that, assuming typical behaviour of college students, universal screening using a rapid, cheap, high specificity test-even if low sensitivity-every two to three days is the optimal strategy. ${ }^{18}$

Frequent testing will not be feasible in all settings, but this strategy is in line with a recommendation from the UK's Independent SAGE Behavioural Advisory Group, that if students in the UK have to physically attend campus, there should be "testing on or before arrival on campus followed up by further regular testing of students and staff." ${ }^{19}$ Testing should also include lecturers and other campus staff (who may be older and at higher mortality risk from infection), and probably students living off-campus nearby.

\section{No blame}

Any prevention strategy that is based on personal responsibility and the expectation that students will never go to parties or have sex is bound to fail. It has been disheartening to watch university leaders blaming students for outbreaks instead of admitting that the university's reopening plans were dangerous. ${ }^{20}$

Behavioural research shows that risk taking peaks in young adulthood and that shaming them for risky behaviours is an ineffective public health strategy. ${ }^{21}$ Instead, we need a harm reduction approach, akin to the one used to promote safer sex. Universities 
must provide guidance on ways to socialise more safely and low risk alternatives to unmasked, covert indoor parties: "Think movies, yoga classes, and concerts-all outdoors with social distancing encouraged and school-branded masks provided." ${ }^{21}$

Finally, universities are centres of learning and should start conducting research to help guide safer reopening. Every university should publish its safety protocols and a daily dashboard showing metrics such as the numbers of tests, cases, hospital admissions, and deaths. These data need to be disentangled from regional data to understand rates both at the university and within the local community. Reopening a university in the middle of a deadly pandemic is a high risk endeavour, and transparency and accountability from university leadership are the least we can expect when they put so many lives on the line.

Competing interests: We have read and understood BMJ policy on declaration of interests and have no interest to declare.

Provenance and peer review: Commissioned; externally peer reviewed.

1 Here's our list of colleges' reopening plans. Chron High Educ 2020 Jul 29. https://www.chronicle.com/article/Here-s-a-List-of-Colleges-/248626.

2 Johns Hopkins University. COVID-19 dashboard. 21 Aug 2020. https://coronavirus.jhu.edu/map.html

3 Treisman R. UNC-Chapel Hill classes to move online after 130 students test positive in first week. NPR2020 Aug 16. https://www.npr.org/sections/coronavirus-live-up-

dates/2020/08/16/903071127/less-than-a-week-after-starting-classes-unc-chapel-hill-reports4-covid-19-clust

4 Chapel Hill UNC. CV-19 Dashboard. 27 Aug 2020. https://carolinatogether.unc.edu/dashboard/

5 Universities scramble to deal with virus outbreaks. US News World Rep 2020 Aug 17. https://www.usnews.com/news/health-news/articles/2020-08-17/virus-clusters-erupt-as-usuniversities-as-semester-begins

6 Tracking coronavirus cases at U.S. colleges and universities. New York Times 2020 Aug 26. https://www.nytimes.com/interactive/2020/us/covid-college-cases-tracker.html

7 Tenforde MW, Kim SS, Lindsell CJ, etalIVY Network InvestigatorsCDC COVID-19 Response TeamIVY Network Investigators. Symptom duration and risk factors for delayed return to usual health among outpatients with COVID-19 in a multistate health care systems network-United States, March-June 2020. MMWR Morb Mortal Wkly Rep 2020;69:993-8. doi: 10.15585/mmwr.mm6930e1 pmid: 32730238

8 Ellul MA, Benjamin L, Singh B, etal. Neurological associations of COVID-19. Lancet Neurol 2020;19:767-83. doi: 10.1016/S1474-4422(20)30221-0 pmid: 32622375

9 Rubino F, Amiel SA, Zimmet P, etal. New-onset diabetes in COVID-19. N Engl J Med 2020;383:789-90. doi: 10.1056/NEJMc2018688 pmid: 32530585

10 Dodd D, Silverstein A. Big ten cancels college football season for fall 2020, hopes to play in spring 2021. CBS Sports 2020 Aug 11. https://www.cbssports.com/college-football/news/big-ten-cancelscollege-football-season-for-fall-2020-hopes-to-play-in-spring-2021/

11 Mack K, Yamey G. After nursing homes and cruise ships, will universities be the next COVID-19 tinderboxes?Time 2020 Jul 16. https://time.com/5867395/will-universities-be-next-covid-19tinderboxes/.

12 Bichsel J, Pritchard A, Li M, McChesney J. Staff in higher education annual report: key findings, trends, and comprehensive tables for 2017-18 academic year. CUPA-HR, 2018.

13 Lopez G. Just 5 states meet these basic criteria to reopen and stay safe. Vox 2020 Aug 19. https://www.vox.com/2020/5/28/21270515/coronavirus-covid-reopen-economy-social-distancingstates-map-data

14 Cheng S-Y, Wang CJ, Shen AC-T, Chang SC. How to safely reopen colleges and universities during COVID-19: experiences from Taiwan. Ann Intern Med 2020:M20-2927. [Epub ahead of print.] doi: 10.7326/M20-2927. pmid: 32614638

15 Boston University. Covid-19 testing data dashboard. https:/www.bu.edu/healthway/communitydashboard/

16 Cornell University. Covid-19 and reactivation planning. https://covid.cornell.edu/testing/dashboard/

17 Centers for Disease Control and Prevention. Interim considerations for institutions of higher education administrators for SARS-CoV-2 testing. 30 Jun 2020. https://www.cdc.gov/coronavirus/2019-ncov/community/colleges-universities/ihe-testing.html

18 Paltiel AD, Zheng A, Walensky RP. Assessment of SARS-CoV-2 screening strategies to permit the safe reopening of college campuses in the United States. JAMA Netw Open 2020;3: doi: 10.1001/jamanetworkopen.2020.16818 pmid: 32735339

19 Independent SAGE. Report 9. Independent SAGE-Behaviour Group consultation statement on universities in the context of SARS-CoV-2. 2020.

20 Mangan K. The student blaming has begun. Chron High Educ 2020 Aug 21. https://www.chronicle.com/article/the-student-blaming-has-begun.

21 Marcus J, Gold G. Colleges are getting ready to blame their students. Atlantic 2020 Jul 21. https://www.theatlantic.com/ideas/archive/2020/07/colleges-are-getting-ready-blame-theirstudents/614410/
This article is made freely available for use in accordance with BMJ's website terms and conditions for the duration of the covid-19 pandemic or until otherwise determined by BMJ. You may use, download and print the article for any lawful, non-commercial purpose (including text and data mining) provided that all copyright notices and trade marks are retained. 